\title{
Identification of nine cryptic species of Candida albicans, C. glabrata, and C. parapsilosis complexes using one-step multiplex PCR
}

\author{
Amir Arastehfar ${ }^{1 \dagger}$, Wenjie Fang ${ }^{1,2 \dagger}$, Weihua Pan ${ }^{2 *}$, Wanqing Liao ${ }^{2}$, Liang Yan² and Teun Boekhout ${ }^{1,2,3^{*}}$
}

\begin{abstract}
Background: Candida albicans, Candida glabrata, and Candida parapsilosis are three prevalent causes of candidiasis, worldwide. These species are considered as nine medically important complex species. Limited knowledge about these newly recognized species prompted us to develop a one-step, multiplex PCR to detect and identify them in clinical settings.

Methods: Primers targeting Hyphal Wall Protein I gene for the C. albicans, C. dubliniensis, C. africana, Intergenic Spacer for the C. glabrata, C. nivariensis, C. bracarensis, and Intein and ITS rDNA for the C. parapsilosis, C. orthopsilosis, and C. metapsilosis were designed. Using 168 CBS reference strains and 280 clinical isolates, the specificity and reproducibility of the developed assay were evaluated.

Results: Our developed assay successfully identified and distinguished all the nine species. No cross-reaction with closely- and distantly-related yeast species, Aspergillus species and human DNA was observed, resulting in 100\% specificity. The ambiguous results obtained by MALDI-TOF for C. albicans and C. africana were corrected by our 9-plex PCR assay. This assay identified all the cryptic complex species from two test sets from Iran and China, correctly.

Conclusions: Our developed multiplex assay is accurate, specific, cost/time-saving, and works without the tedious DNA extraction steps. It could be integrated into routine clinical laboratories and as a reliable identification tool and has the potential to be implemented into epidemiological studies to broaden the limited knowledge of cryptic species complexes.
\end{abstract}

Keywords: Cryptic species, Candida, Molecular diagnosis, Multiplex PCR

\section{Introduction}

Candida albicans, C. glabrata, and C. parapsilosis were reported to be the three most clinically important Candida species [1]. Due to the inclusion of newly designated species through taxonomic studies, these three Candida species are now considered cryptic complex species, including C. albicans, C. africana,

\footnotetext{
* Correspondence: panweihua@smmu.edu.cn;

t.boekhout@westerdijkinstitute.nl

${ }^{\dagger}$ Amir Arastehfar and Wenjie Fang contributed equally to this work.

2Department of Dermatology, Shanghai Key Laboratory of Molecular Medical

Mycology, Shanghai Institute of Medical Mycology, Shanghai Changzheng

Hospital, Second Military Medical University, Shanghai 200003, China

${ }^{1}$ Westerdijk Fungal Biodiversity Institute, Utrecht 3584, the Netherlands

Full list of author information is available at the end of the article
}

and C. dubliniensis (as C. albicans complex) [2, 3], C. glabrata, C. nivariensis, and C. bracarensis (as C. glabrata complex) [4, 5], and C. parapsilosis, $C$. orthopsilosis, and C. metapsilosis (as C. parapsilosis complex) [6]. Despite the fact that for more than a decade these cryptic species have been introduced, still limited knowledge exists on their distribution, pathogenicity, and antifungal susceptibility pattern. Moreover, from an evolutionary standpoint, identification and discrimination of these cryptic species complexes could shed light on pathogenicity acquisition, as Pryszcz et al. (2015) found C. metapsilosis as a highly heterozygous opportunistic pathogen arose from a two parental lineages that were not pathogenic [7].

(c) The Author(s). 2018 Open Access This article is distributed under the terms of the Creative Commons Attribution 4.0 International License (http://creativecommons.org/licenses/by/4.0/), which permits unrestricted use, distribution, and reproduction in any medium, provided you give appropriate credit to the original author(s) and the source, provide a link to the Creative Commons license, and indicate if changes were made. The Creative Commons Public Domain Dedication waiver (http://creativecommons.org/publicdomain/zero/1.0/) applies to the data made available in this article, unless otherwise stated. 
Biochemical and morphological tests failed to unequivocally identify and differentiate these cryptic species, which is attributed to the presence of similar phenotypic properties among the complexes [8]. Accordingly, various methodologies, including amplified fragment length polymorphism (AFLP) [9], matrix-assisted laser desorption-time of flight (MALDI-TOF) [10], sequencing of ITS rDNA [11] have been used to tackle this problem. Nowadays, due to affordability and the high reproducibility of PCR, myriad aspects of biology have been revolutionized throughout the world $[12,13]$. In line with this, identification and differentiation of Candida albicans, Candida glabrata, and Candida parapsilosis complexes representatives through fast and simple conventional PCR by targeting hyphal wall protein 1(HWP1) gene [14], large ribosomal protein 31 (RPL31) gene [15], and vacuolar ATPase (VMA) gene [16], have been addressed. However, the simultaneous detection of all of aforementioned nine medically important cryptic species in a single reaction was not described, previously.

Consequently, the aim of this study was to develop an easy-to-perform, low-cost, highly specific and accurate, multiplex PCR assay capable of differentiation of all these nine medically important Candida species, without tedious DNA extraction steps and directly through mixing of pure colonies into the PCR master mix.

\section{Materials and methods}

\section{Isolates and growth conditions}

Four hundred forty-eight isolates including, 168 reference strains (111 target cryptic strains and 57 non-target strains representing 57 species) from Westerdijk Fungal Biodiversity Institute (Additional file 1: Table S1) and 280 clinical isolates comprising only cryptic species complexes (Table 1) were included. Chinese clinical isolates $(n=145)$ were pooled from a Chinese collection $(n=1500)$, and included cryptic species of $C$. glabrata and $C$. parapsilosis complexes and the Iranian clinical isolates $(n=135)$ included cryptic species complexes of $C$. albicans. Clinical isolates were from different anatomical sites, ranging from nail, sputum, urine and bronchial fluids to blood and were collected from different hospitals in Iran and China (Table 1). CBS reference strains were used for optimization and specificity testing, while clinical isolates used for confirming reproducibility of the developed multiplex PCR assay. Isolates were grown on Glucose Yeast Extract Peptone Agar (Westerdijk Fungal Biodiversity Institute, Utrecht, Netherlands) at $25^{\circ} \mathrm{C}$ for $48 \mathrm{~h}$.

\section{DNA extraction}

DNA extraction was carried out using CTAB and phenol-chloroform method as described previously [17]. Briefly, a full loop of fresh yeasts colonies was suspended in $700 \mu \mathrm{L}$ of CTAB buffer followed by bead beating (TissueLyzer II, QIAGEN, Hannover, Germany) for $3 \mathrm{~min}, 3000$ beats/minute. After incubation for $60 \mathrm{~min}$
Table 1 Clinical isolates utilized for reproducibility and validation testing

\begin{tabular}{lll}
\hline Species & Number of Isolates & Origin \\
\hline Iran $(n=135)$ & & \\
C. albicans & 128 & Urine, blood \\
C. africana & 3 & Vagina \\
C. dubliniensis & 4 & Urine \\
China $(n=145)$ & & \\
C. nivarensis & 2 & Sputum \\
C. glabrata & 87 & Urine, blood, sputum, BALF \\
C. metapsilosis & 20 & Sputum \\
C. orthopsilosis & 6 & Nail, blood, mouths \\
C. bracarensis & 2 & Sputum \\
C. parapsilosis & 28 & Urine, blood, nail, sputum
\end{tabular}

${ }^{\mathrm{a}} \mathrm{BALF}$ bronchoalveolar lavage fluid

at $55{ }^{\circ} \mathrm{C}, 700 \mu \mathrm{L}$ of phenol-chloroform was added. Upon vortexing and centrifugation for $20 \mathrm{~min}$ at $14000 \mathrm{rpm}$, $4{ }^{\circ} \mathrm{C}, 400 \mu \mathrm{L}$ of supernatant was added to isopropanol. Finally, upon washing with $70 \%$ ethanol and drying the DNA samples on air, the pellets were suspended in Tris-EDTA (10 mM Tris Base, $1 \mathrm{mM}$ EDTA, pH 8.0) buffer. DNA purity and quantity was assessed using NanoDrop and Qubit Broad range kit (Invitrogen) and the quality was evaluated by electrophoretic separation of $5 \mu \mathrm{l}$ of DNA samples on $1 \%$ agarose gel.

\section{Primer design}

Target sequences were retrieved from NCBI website (https://blast.ncbi.nlm.nih.gov/Blast.cgi). Primers utilized in this study were all designed by authors, and are listed and depicted in Table 2 and Fig. 1. Primers were selected if 1) lack of cross-reactivity with each other and other non-target species, 2) Compatible PCR product size, 3) compatible in Tm values, and 4) positioned in the most stable part of target loci. Gaps and mismatches with non-target species were located in the 3 end of primers, hence allow specific amplification of target species. Online free software of Integrated DNA Technology was used to calculate Tm and Delta G of primers (https:// eu.idtdna.com/calc/analyzer).Primers were manufactured by Integrated DNA Technology (IDT) Company.

\section{PCR condition}

The PCR reaction was optimized in a final volume of $50 \mu \mathrm{L}$ as follows: $37 \mu \mathrm{L}$ MiliQ water (Merck Millipore, Billerica, Massachusetts, United States), $5 \mu \mathrm{L}$ 10X buffer, $1.5 \mathrm{mM} \mathrm{MgCl}_{2}, 2.5$ units of Taq enzyme (Bio Taq DNA Polymerase, Biolab), $0.2 \mathrm{mM}$ of mixed dNTP (dNTP mix, $100 \mathrm{Mm}$, Biolab), C. albicans complex primers pair $10 \mathrm{p}$-mole each one, $5 \mathrm{p}$-mole for the rest of the primers 
Table 2 Sequence of utilized primers in this study

\begin{tabular}{lll}
\hline Primer Name & Primer sequences & Annotation \\
\hline PACF & GCTACCACTTCAGAATCATCATC & Universal forward (PACF) and reverse (PACR) primers for C. albicans, C. dubliniensis \\
PACR & AGATCAAGATGCAGCAATACCAA & and . africana \\
PGCF & TCACTITCAACTGCTITCGC & Universal forward primers for C. glabrata, C. nivariensis and C. bracarensis \\
GR & TGCGAGTCATGGGCGGAA & Reverse primer only for C. glabrata \\
NR & ACCCCAGAGGCATAAATAGC & Reverse primer only for $C$. nivariensis \\
BR & GCAACTGGACGAAAGTGC & Reverse primer only for C. bracarensis \\
PF & GCGGAAGGATCATTACAGAATG & Forward (PF) and reverse (PR) primers specifically for C. parapsilosis \\
PR & CTGGCAGGCCCCATATAG & \\
OMF & GAGAAAGCACGCCTCTTTGC & Universal forward (OMF) and reverse (OMR) primers for C. orthopsilosis \\
OMR & TCAGCATTTTGGCTCTTGC & and C. metapsilosis
\end{tabular}

(C. glabrata and C. parapsilosis complex primers), and $1 \mu \mathrm{L}$ of DNA template.

PCR (2720 Thermal Cycler,, Applied Biosystems, Waltham, Massachusetts, USA) used the following program, pre-denaturation for $5 \mathrm{~min}$ at $94{ }^{\circ} \mathrm{C}, 35 \mathrm{cy}$ cles of $94{ }^{\circ} \mathrm{C}$ for $30 \mathrm{~s}, 60{ }^{\circ} \mathrm{C}$ for $30 \mathrm{~s}, 72{ }^{\circ} \mathrm{C}$ for $30 \mathrm{~s}$, and final extension at $72{ }^{\circ} \mathrm{C}$ for $8 \mathrm{~min}$. PCR products were run on $2 \%$ agarose gel for $70 \mathrm{~min}(8 \mathrm{Volt} / \mathrm{cm})$, stained with GelRed (BioTium Corporation, USA) and visualized using gel documentation with exposure time of $4 \mathrm{~s}$ (Gel Doc XR $\mathrm{XR}^{+}$BioRad, California, USA). In order to prepare in-house ladders, $10 \mu \mathrm{L}$ of PCR products from controls $(90 \mu \mathrm{L}), 10 \mu \mathrm{L}$ deionized water, and $20 \mu \mathrm{L}$ of $10 \mathrm{X}$ loading dye were mixed. $15 \mu \mathrm{L}$ of prepared in-house ladders were utilized as marker to aid in identifying target species (Additional file 2: Figure $\mathrm{S} 1$ ).

\section{Optimization of 9-plex PCR assay using CBS reference strains}

After initial successful amplification from CBS 2691 (C. albicans), CBS 7987 (C. dubliniensis), CBS 8781 (C. africana), CBS 138 (C. glabrata), CBS 9983 (C. nivariensis), CBS 10154 (C. bracarensis), CBS 11045 (C. parapsilosis), CBS 10906 (C. orthopsilosis) and CBS 2916 (C. metapsilosis), A panel of 111 CBS reference strains (Additional file 1: Table S1) encompassing only cryptic species of C. albicans, C. glabrata, $C$. parapsilosis complexes were further tested with our 9-plex PCR.

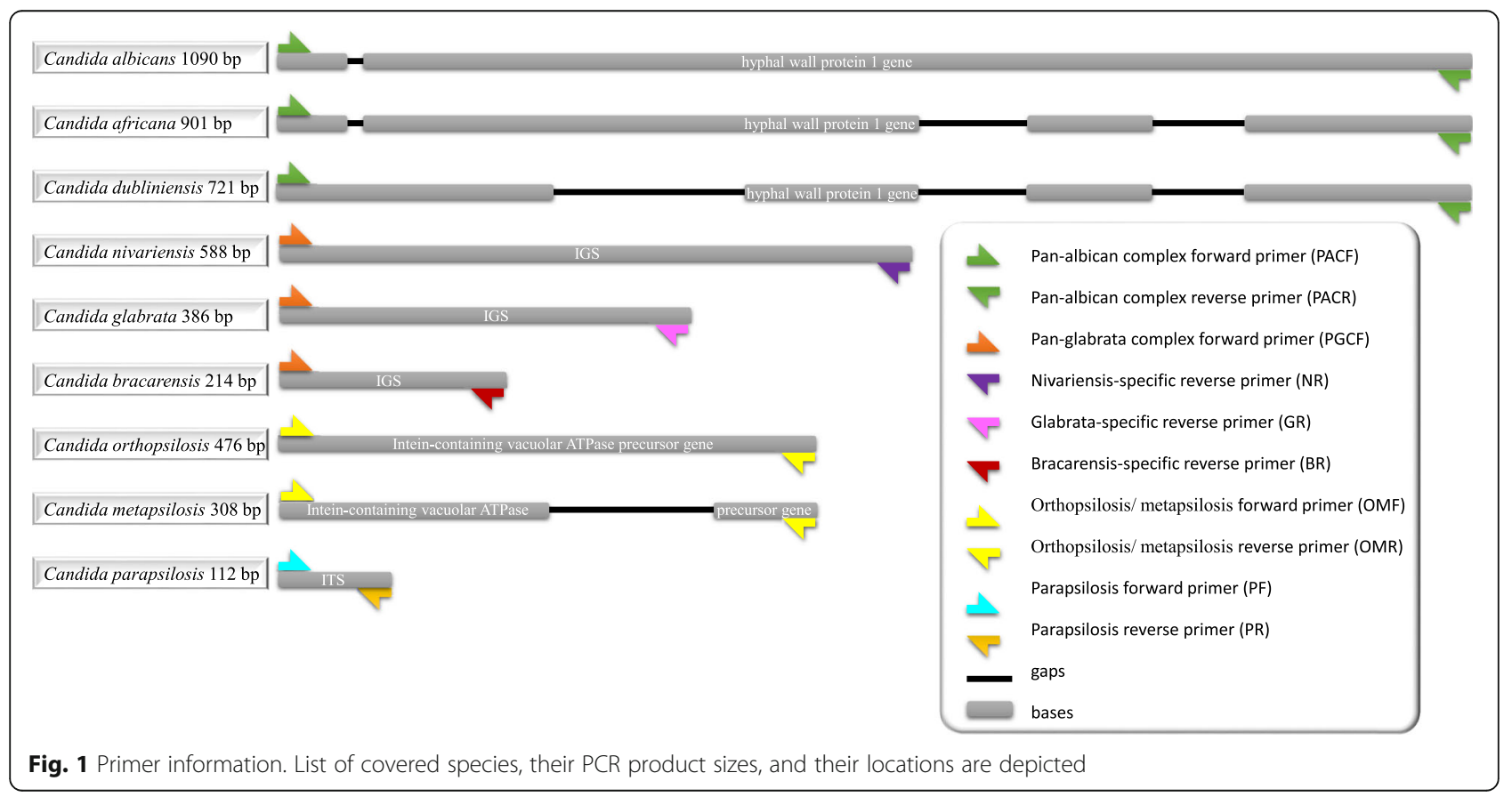




\section{Specificity testing}

To evaluate the specificity of the 9-plex PCR assay, 100 DNA samples containing 57 closely- and distantly-related yeast species, Aspergillus spp., and human DNA (from blood) and 43 target strains pooled from CBS reference (optimization test set) were prepared in a blinded fashion (blind test set) (Table 1). For preparation of the specificity test set, two technicians were involved. The first technician randomly dispersed DNA samples and serially coded them from one to 100 . The second technician subjected the specificity blind test set to the optimized multiplex PCR. The first technician was provided with the results derived from PCR and the consistency of the results was checked with the CBS identity of each strain.

\section{Pure colony testing}

In order to eliminate the DNA extraction step and confirm the compatibility of the multiplex assay, single colonies of yeast species derived from the blind test set were subjected to PCR as a template (except for Rhodotorula mucilaginosa). Briefly, a single colony $\left(\approx 1 \mathrm{~mm}^{3}\right)$ was suspended in the prepared PCR master mix $(50 \mu \mathrm{l})$ as mentioned earlier.

\section{Validation of 9-plex multiplex PCR using clinical isolates} Upon optimization of the multiplex PCR assay using CBS reference strains, specificity and pure colony testing, a panel of clinical isolates $(n=280)$ (Table 1) prepared in a blind fashion were subjected to the 9-plex assay. One technician performed the LSU sequencing and MALDI-TOF. Upon, identification, the first technician coded the yeast culture plates from 1 to 280 , and then a new random number (integer number from 1 to 280) for each plate was generated by SPSS random number generator (version 21, International Business Machines Corp, Armonk, New York, United States) and used as blind test number. The second technician subjected the blind test set to the optimized multiplex PCR. The first technician was provided with the results derived from PCR and the consistency of these results with MALDI-TOF and sequencing were evaluated.

\section{MALDI-TOF}

The full extraction method using MALDI-TOF MS (Bruker Biotyper, MicroFlex, LT, Bruker Daltonics, Bremen, Germany) was followed, according to the manufacturer's instructions (https://www.bruker.com/fileadmin/user_upload/8-PDF-Docs/Separations_MassSpectrometry/InstructionForUse/IFU_268711_267615_226413_MALDI_Biotarget_48_Rev1.pdf). Briefly, after suspending of pure colonies in $300 \mu \mathrm{L}$ of MiliQ water, $900 \mu \mathrm{L}$ of absolute ethanol was added. After centrifugation step $(14,000 \mathrm{rpm}$, $3 \mathrm{~min}$, room temperature) the supernatant was discarded and another centrifugation step was repeated to totally discard the supernatant. Subsequently, 70\% formic acid (Sigma Aldrich, St. Louis, Missouri, United States) was added and upon five minutes incubation at room temperature equal amount of Acetonitrile was added. After a final centrifugation step $(14,000 \mathrm{rpm}, 3 \mathrm{~min}$, room temperature) $1 \mu \mathrm{L}$ of clear supernatant was transferred onto the 96-well target plate. Subsequently, $1 \mu \mathrm{L}$ of matrix was overlaid on the top of air dried samples. Finally, the 96 well target plate was loaded into the MALDI-TOF device.

\section{Sequencing}

In order to ensure that the designed primers targeted the right genes, the amplified PCR products were subject to bidirectional dideoxy chain terminated Sanger sequencing using the respective primers. Obtained sequences were subjected to online searching database of NCBI (https://blast.ncbi.nlm.nih.gov/Blast.cgi).

The ribosomal DNA large subunit (LSU) primers including LROR (5'-ACCCGCTGAACTTAAGC-3') and LR5 (5' -TCCTGAGGGAAACTTCG-3') were exploited to address the identity of each isolate [18]. Sequences obtained for each isolate was subject to BLAST online database tool (https://blast.ncbi.nlm.nih.gov/Blast.cgi).

\section{Results \\ Development of 9-plex PCR assay using CBS reference strains}

Subjecting 111 CBS reference strains belonging to the species complexes of C. albicans $(n=55)$, C. glabrata $(n=28)$, and C. parapsilosis $(n=28)$ successfully differentiated and identified the nine target species (Fig. 2). Although, the lengths of PCR products were different from those were designed, target species were unequivocally distinguishable from one another (Figs. 1 and 2 and Table 3). In order to prevent misidentifications it is advised to prepare in-house master mixes in large scale by mixing PCR products of target species and storing them at $4{ }^{\circ} \mathrm{C}$ for future identification purposes.

\section{Specificity testing using the blind test set}

Subjecting 100 DNA samples (containing 66 fungal species) to our 9-plex PCR assay ranging from closely- and distantly-related yeast species, Aspergillus spp. resulted in $100 \%$ specificity and no cross-reaction with any other fungal species. Additionally, subjecting human DNA to our 9-plex PCR assay, showed no cross-reaction either.

\section{Pure colony testing}

Subjecting 105 yeast pure colonies from 61 yeast species pooled from the optimization test set (Additional file 1: Table S1) resulted in successful amplification of all nine target species. No PCR inhibition by cell components was observed, indicating that pure colonies are compatible 


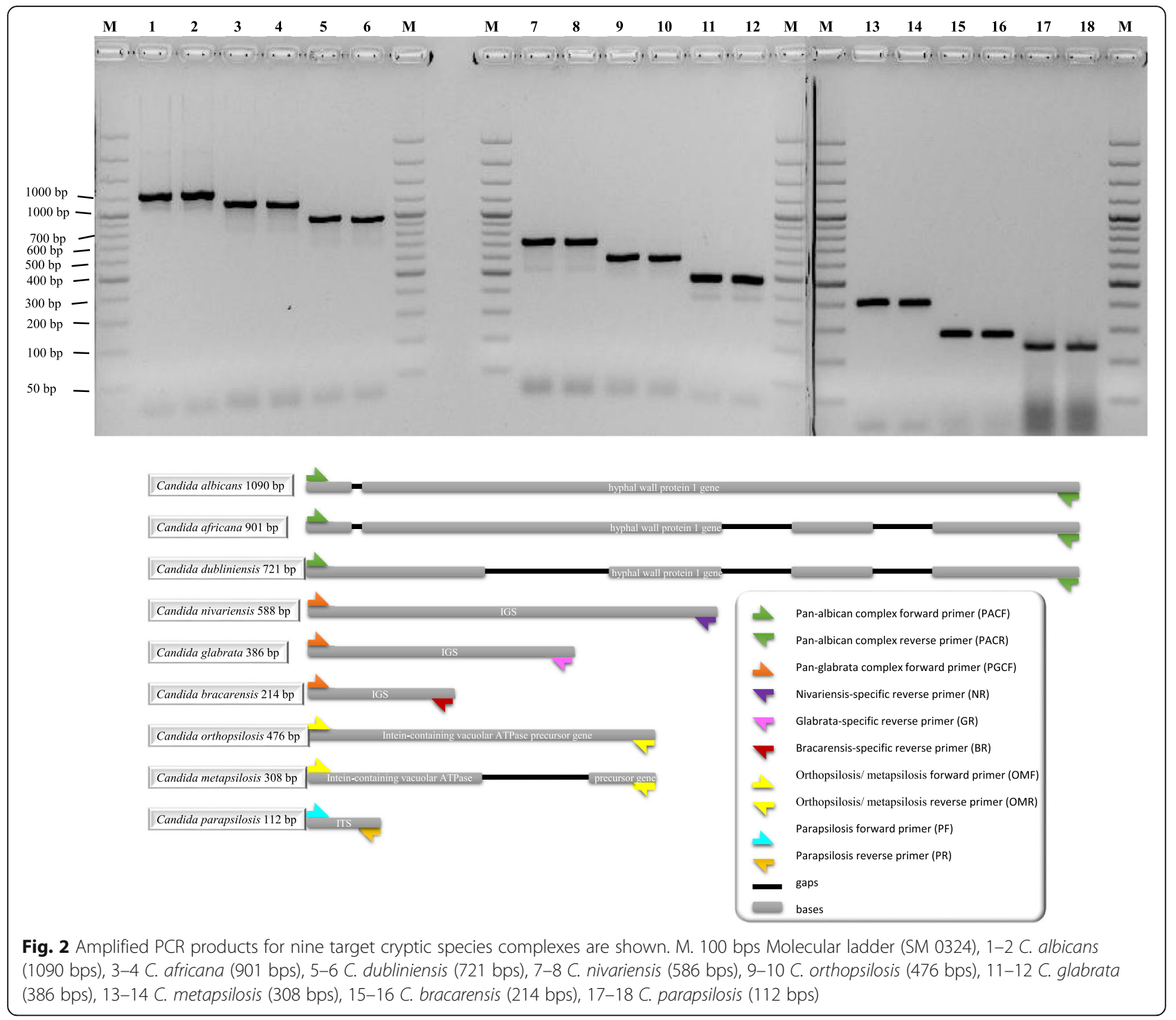

with the 9-plex PCR. Compatibility of our 9-plex PCR with pure colony testing allowed decreasing turn-around time from $7 \mathrm{~h}$ to $4 \mathrm{~h}$.

\section{Agreement of 9-plex PCR assay with MALDI-TOF MS}

Results obtained from our 9-plex PCR for 280 clinical isolates were compared with MALDI-TOF (Table 4). Previously in Westerdijk Fungal Biodiversity Institute, clinically isolated yeast species were identified by MALDI-TOF MS and it showed $98-100 \%$ agreement with sequencing $[19,20]$. Hence, in this study MALDI-TOF MS along with Sanger sequencing were used as validation tools. Additionally, the spectra for many yeast species utilized in brewery have been added to the MALDI-TOF CBS in-house database. Of 131 strains identified as $C$. albicans using MALDI-TOF MS, our 9-plex PCR assay identified
128 as $C$. albicans and three as $C$. africana. The rest of cryptic species complexes of C. glabrata $(n=91)$, and $C$. parapsilosis $(n=54)$ were all identified correctly by MALDI-TOF MS. The overall agreement between MALDI-TOF MS and our 9-plex PCR assay was $98.93 \%$.

\section{Agreement of 9-plex PCR assay with sequencing}

Results obtained from our 9-plex PCR was 100\% consistent with sequencing of D1/D2 domains of LSU rDNA for 280 clinical strains (Table 4). Cryptic species complexes of $C$. parapsilosis $(n=54)$ and $C$. glabrata $(n=91)$ were all clearly distinguishable using sequencing of respective domain. Despite the fact that, $C$. dubliniensis $(n=4)$ and $C$. albicans $(n=128)$ clearly were distinguishable using sequencing of respective domain, $C$. africana and $C$. albicans showed > 99\% similarity, and, hence, making their discrimination at 
Table 3 Expected and actual PCR products on gel are shown. Despite of deviation of amplicon sizes in both individual PCR products and home-made ladder containing mixture of PCR products, target species were clearly distinguishable from each other

\begin{tabular}{llll}
\hline Target species & $\begin{array}{l}\text { Expecetd PCR } \\
\text { product size }\end{array}$ & $\begin{array}{l}\text { Actual home-made ladder } \\
\text { PCR product sizes on gel (approximately) }\end{array}$ & $\begin{array}{l}\text { Actual indidividual PCR product } \\
\text { size on gel (approximately) }\end{array}$ \\
\hline Candida albicans & $1090 \mathrm{bps}$ & $950 \mathrm{bps}$ & $1200 \mathrm{bps}$ \\
Candida africana & $901 \mathrm{bps}$ & $800 \mathrm{bps}$ & $1100 \mathrm{bps}$ \\
Candida dubliniensis & $721 \mathrm{bps}$ & $600 \mathrm{bps}$ & $950 \mathrm{bps}$ \\
Candida nivariensis & $588 \mathrm{bps}$ & $500 \mathrm{bps}$ & $700 \mathrm{bps}$ \\
Candida orthopsilosis & $476 \mathrm{bps}$ & $>400 \mathrm{bps}$ & $576 \mathrm{bps}$ \\
Candida glabrata & $386 \mathrm{bps}$ & $>350 \mathrm{bps}$ & $486 \mathrm{bps}$ \\
Candida metapsilosis & $308 \mathrm{bps}$ & $280 \mathrm{bps}$ & $400 \mathrm{bps}$ \\
Candida bracarensis & $214 \mathrm{bps}$ & $200 \mathrm{bps}$ & $300 \mathrm{bps}$ \\
Candida parapsilosis & $112 \mathrm{bps}$ & $100 \mathrm{bps}$ & $250 \mathrm{bps}$ \\
\hline
\end{tabular}

the species level difficult. However, our 9-plex PCR assay clearly discriminated the two closely related species complexes of $C$. albicans and C. africana. Consistently, 9-plex PCR assay distinctly identified all of the cryptic species complexes as distinct fragment on the gel. The overall agreement between sequencing of D1/D2 LSU rDNA was $100 \%$.

\section{Discussion}

Representatives of the cryptic species of Candida albicans, Candida glabrata, and Candida parapsilosis complexes account for the majority of candidiasis cases [21]. Appropriate identification and differentiation of cryptic species complexes is clinically relevant, as not only there are differences on virulence and antifungal susceptibility patterns among species within the same complex, but also contradictory observations for antifungal susceptibility patterns among different studies have been reported [5, 22-25]. Due to facing these contradictory results along with the limited epidemiological data for cryptic species complexes, the genuine distribution and antifungal susceptibility profiles of these species in different geographical locations remained unclear. Moreover, as antifungal susceptibility profile of cryptic species within the same complex are varied, identification down to the species level is imperative to establish the appropriate antifungal therapy [24, 26, 27]. In line with this, providing epidemiologists and small laboratories with a fast, accurate, specific, and cheap means of identification to disclose the prevalence and antifungal susceptibility profiles of isolates belonging to cryptic Candida species. Accordingly, we have developed and validated an inexpensive, reliable, accurate, specific, and user friendly multiplex PCR assays capable of identifying nine cryptic species in one assay.

From different perspectives including, time needed to finish the experiments, required expenses and need of trained technicians our assays is comparable to other PCR-based assay and platforms such as MALDI-TOF.

Application of cryptic species complexes strains isolated in clinical settings with our 9-plex PCR assay and its comparison with results obtained by Sanger sequencing of D1/D2 domain of LSU rDNA, revealed $100 \%$ consistency between these techniques. However, due to the high similarity between C. albicans and C. africana in the sequences of the D1/D2 and ITS rDNA fragments (99.3-100\%), distinguishing these two species is difficult

Table 4 Comparison of 9-plex PCR with CBS in-house MALDI-TOF database and sequencing of D1/D2 LSU rDNA

\begin{tabular}{|c|c|c|c|}
\hline Species & Multiplex PCR & MALDI-TOF & Sequencing \\
\hline C. albicans $(n=128)$ & C. albicans $(n=128)$ & C. albicans $(n=128)$ & C. albicans $(n=128)$ \\
\hline C. dubliniensis $(n=4)$ & C. dubliniensis $(n=4)$ & C. dubliniensis $(n=4)$ & C. dubliniensis $(n=4)$ \\
\hline C. africana $(n=3)$ & C. africana $(n=3)$ & C. albicans $(n=3)$ & C. africana $(n=3)^{a}$ \\
\hline C. glabrata $(n=87)$ & C. glabrata $(n=87)$ & C. glabrata $(n=87)$ & C. glabrata $(n=87)$ \\
\hline C. nivariensis $(n=2)$ & C. nivariensis $(n=2)$ & C. nivariensis $(n=2)$ & C. nivariensis $(n=2)$ \\
\hline C. bracarensis $(n=2)$ & C. bracarensis $(n=2)$ & C. bracarensis $(n=2)$ & C. bracarensis $(n=2)$ \\
\hline C. parapsilosis $(n=28)$ & C. parapsilosis $(n=28)$ & C. parapsilosis $(n=28)$ & C. parapsilosis $(n=28)$ \\
\hline C. orthopsilosis $(n=6)$ & C. orthopsilosis $(n=6)$ & C. orthopsilosis $(n=6)$ & C. orthopsilosis $(n=6)$ \\
\hline C. metapsilosis $(n=20)$ & C. metapsilosis $(n=20)$ & C. metapsilosis $(n=20)$ & C. metapsilosis $(n=20)$ \\
\hline
\end{tabular}

a Similarity between C. albicans and C. africana using sequencing of D1/D2 LSU rDNAwas more than 99\%

This library has been enriched with a diverse range of yeast species utilized in brewery 
[28]. Consistently, the sequencing of LSU rDNA fragment in C. africana showed $>99 \%$ similarity with $C$. albicans. Importantly, application of our 9-plex PCR could discriminate these two species. Like DNA microarray [29] and pyrosequencing [30], Sanger sequencing requires highly trained technicians and more turn-around time [8], while our multiplex PCR assay is straightforward and running of the whole application (from master mix preparation to visualization on the gel) only consumes four hours. In terms of expenses, only $0.75-1$ euro is enough to finalize the results on the gel electrophoresis, however, sequencing require specific devices and is more expensive. However, in order to resolve the issue of discrepancy between the length of predicted and actual PCR products we suggest to use either our in-house ladder or to run the amplicons of each control species individually in a separate lane.

Our multiplex PCR successfully identified all C. africana isolates and, hence, improved the results obtained from MALDI-TOF. Except for $C$. africana strains $(n=3)$, Bruker MALDI-TOF MS could identify the rest of cryptic species complexes, resulting in $98.93 \%$ agreement with our multiplex PCR assay. Variability in accuracy of commercial MALDI-TOF MS database for identification of uncommon and cryptic Candida species [9, 31, 32], inability of the Bruker MALDI-TOF to distinguish $C$. africana from $C$. albicans, and incompetence of VITEK MS systems for identification of $C$. bracarensis, $C$. nivariensis, and $C$. orthopsilosis and low cut-off value of Bruker MS systems $(<1.700)$ for identification of $C$. bracarensis complex reinforced the urge for molecular identification tools [22, 33]. On the other hand, unlike the domination of PCR even in developing countries [12, 13], MALDITOF is a newer introduced platform, mainly restricted to large or reference laboratories [34-36].

Unlike, AFLP [9] and RFLP [37], there is no need for restriction of the PCR products, several visualization steps and reading of the results are straightforward. Muriel Cornet et al. (2011) used PCR-RFLP, to identify all eight cryptic species except for C. africana. However, this method used three primers targeting ribosomal intergenic spacer (IGS), tedious post-PCR restriction and required electrophoretic visualization twice making this experiment daunting, time consuming, and expensive [37]. Additionally, digestion of PCR products with restriction enzymes generated multiple fragments, in turn, makes the interpretation difficult when compared to banding pattern of reference strains.

The successful identification of all nine cryptic species in one tube, complements previous studies identifying members of the species complexes of Candida albicans [14], Candida glabrata [15], and Candida parapsilosis [16] using three separate tubes, and, hence, is time- and cost-saving.
Application of broad diversity of yeast species, five Aspergillus species, and human DNA for specificity testing and inclusion of an extensive number of CBS reference strains and clinical isolates, showed that our 9-plex PCR is 100\% specific. As a result, our assay circumvents the imperfections of phenotypic assays (CHROMagar, VITEK 2 and ID $32 \mathrm{C})$ that suffer from the lack of specificity [38, 39]. Additionally, subjecting various populations of the same species to phenotypic assay could showed various results [32, 40, 41]. Accordingly, as suggested by Griseo et al. (2015), small clinical laboratories can take advantage of specific phenotypic methods supplemented with easy-toperform PCR-based approaches to identify and report isolated cryptic Candia species [8].

\section{Conclusion}

Due to the problems with the identification and discrimination of cryptic Candida species from their closest relatives, there is still uncertainty and unclarity about their epidemiology, pathogenicity and antifungal susceptibility pattern $[43,44]$. Consequently, developing reliable, specific, cost and labor effective methods is necessary. Successful testing of specificity and validation using a broad range of CBS reference strains and clinical isolates, revealed the potential of this assay to be implemented in routine diagnostics and epidemiological studies. As C. albicans, C. glabrata, and C. parapsilosis complex species constitute $80-90 \%$ of candidiasis cases, identification of all nine cryptic species within one multiplex PCR assay, could be of a great assistance.

\section{Additional files}

Additional file 1: Table S1. CBS reference strains utilized for optimization of 9-plex PCR. (DOCX 20 kb)

Additional file 2: Figure S1. Comparison of home-made ladder and Thermofisher commercial ladder (SM0323). Obviously, amplicons of all target species are distinguished and differentiated from one another. (JPG $79 \mathrm{~kb})$

\section{Acknowledgements}

We would like to Thank Dr. Kamiar Zomorodian, Sadegh Khodavaisy, Hamid Badali, Weiwei Jiang, and Ferry Hagen for kind provision of clinical strains and revision of the manuscript.

\section{Funding}

This project has received funding from the European Union's Horizon 2020 research and innovation programme under the Marie Sklodowska-Curie grant agreement No 642095, National Health Department of China [2018ZX10101003], National Natural Science Foundation of China [31770161], Second Military Medical University [2017JZ47] and Shanghai Science and Technology Committee [14DZ2272900 and 14495800500].

Availability of data and materials

All data are presented in this manuscript.

\section{Authors' contributions}

AA and WJF have designed the study participated in study design and practical works, and drafted the manuscript. WHP and TB have contributed 
in study design and revision. WL and LY helped with study design, strain provision, drafting and revising manuscript. All authors read and approved the final version

\section{Ethics approval and consent to participate}

Not applicable.

\section{Consent for publication}

Not applicable.

\section{Competing interests}

Weihua Pan is the editor of BMC Infectious Diseases and we declare that her co-authorship has not influenced the editorial processes.

\section{Publisher's Note}

Springer Nature remains neutral with regard to jurisdictional claims in published maps and institutional affiliations.

\section{Author details \\ 'Westerdijk Fungal Biodiversity Institute, Utrecht 3584, the Netherlands. ${ }^{2}$ Department of Dermatology, Shanghai Key Laboratory of Molecular Medical Mycology, Shanghai Institute of Medical Mycology, Shanghai Changzheng Hospital, Second Military Medical University, Shanghai 200003, China. ${ }^{3}$ Institute of Biodiversity and Ecosystem Dynamics, University of Amsterdam, Amsterdam 1012 WX, the Netherlands.}

\section{Received: 13 February 2018 Accepted: 13 September 2018}

\section{Published online: 25 September 2018}

\section{References}

1. Magill SS, Edwards JR, Bamberg W, Beldavs ZG, Dumyati G, Kainer MA, et al. Multistate point-prevalence survey of health care-associated infections. N Engl J Med. 2014;370:1198-208. https://doi.org/10.1056/NEJMoa1306801.

2. Tietz H-J, Hopp M, Schmalreck a, Sterry W, Czaika V. Candida africana sp. nov., a new human pathogen or a variant of Candida albicans? Mycoses. 2001:44:437-45. https://doi.org/10.1046/j.1439-0507.2001.00707.x.

3. Sullivan DJ, Westerneng TJ, Haynes KA, Bennett DE, Coleman DC. Candida dubliniensis Sp-Nov - phenotypic and molecular characterization of a novel species associated with Oral Candidosis in Hiv-infected individuals. Microbiology-Uk. 1995;141:1507-21.

4. Alcoba-flórez J, Méndez-álvarez S, Guarro J, Pérez-roth E, Arévalo P, Cano J, et al. Phenotypic and molecular characterization of Candida nivariensis sp . Nov ., a possible new opportunistic fungus. J Clin Microbiol. 2005;43:4107-11.

5. Bishop JA, Chase N, Magill SS, Kurtzman CP, Fiandaca MJ, Merz WG. Candida bracarensis detected among isolates of Candida glabrata by peptide nucleic acid fluorescence in situ hybridization: susceptibility data and documentation of presumed infection. J Clin Microbiol. 2008;46:443-6.

6. Tavanti A, Davidson AD, Gow NAR, MCJ M, Odds FC. Candida orthopsilosis and Candida metapsilosis spp. nov. to replace Candida parapsilosis groups II and III. J Clin Microbiol. 2005;43:284-92.

7. Pryszcz LP, Németh T, Saus E, Ksiezopolska E, Hegedüsová E, Nosek J, et al. The genomic aftermath of hybridization in the opportunistic pathogen Candida metapsilosis. PLoS Genet. 2015:11:1-29.

8. Criseo G, Scordino F, Romeo O. Current methods for identifying clinically important cryptic Candida species. J Microbiol Methods. 2015;111:50-6. https://doi.org/10.1016/.j.mimet.2015.02.004.

9. De Carolis E, Hensgens LAM, Vella A, Posteraro B, Sanquinetti M, Senesi S, et al. Identification and typing of the Candida parapsilosis complex: MALDI-TOF MS vs. AFLP. J Music Ther. 2015;52:123-30.

10. Sendid B, Ducoroy P, François N, Lucchi G, Spinali S, Vagner O, et al. Evaluation of MALDI-TOF mass spectrometry for the identification of medically-important yeasts in the clinical laboratories of Dijon and Lille hospitals. Med Mycol. 2013;51:25-32.

11. TM P SP, ID K, GW C. Rapid identification of fungi by sequencing the ITS and ITS2 regions using an automated capillary electrophoresis system. Med Mycol. 2003:41:369-81.

12. Ragheb SM, Jimenez L. Polymerase chain reaction/rapid methods are gaining a foothold in developing countries. PDA J Pharm Sci Technol. 2014; 68:239-55.
13. World Health Organization. Establishment of PCR laboratory in developing countries. 2016. http://apps.who.int/iris/bitstream/10665/249549/5/ 9789290225317-Eng.pdf?ua=1.

14. Romeo O, Criseo G. First molecular method for discriminating between Candida africana, Candida albicans, and Candida dubliniensis by using hwp1 gene. Diagn Microbiol Infect Dis. 2008;62:230-3.

15. Enache-Angoulvant A, Guitard J, Grenouillet F, Martin T, Durrens P, Fairhead C, et al. Rapid discrimination between Candida glabrata, Candida nivariensis, and Candida bracarensis by use of a singleplex PCR. J Clin Microbiol. 2011:49:3375-9.

16. Prandini THR, Theodoro RC, Bruder-Nascimento ACMO, Scheel CM, Bagagli E. Analysis of inteins in the Candida parapsilosis complex for simple and accurate species identification. J Clin Microbiol. 2013;51:2830-6.

17. Theelen B, Silvestri M, Guého E, Belkum A, Boekhout T. Identification and typing of Malassezia yeasts using amplified fragment length polymorphism (AFLPTm), random amplified polymorphic DNA (RAPD) and denaturing gradient gel electrophoresis (DGGE). FEMS Yeast Res. 2001;1:79-86. https:// doi.org/10.1111/j.1567-1364.2001.tb00018.x.

18. Stielow JB, Lévesque CA, Seifert KA, Meyer W, Irinyi L, Smits D, et al. One fungus, which genes? Development and assessment of universal primers for potential secondary fungal DNA barcodes. Persoonia - Mol Phylogeny Evol Fungi. 2015;35:242-63. https://doi.org/10.3767/003158515X689135.

19. Taj-Aldeen SJ, Kolecka A, Boesten R, Alolaqi A, Almaslamani M, Chandra P, et al. Epidemiology of candidemia in Qatar, the Middle East: performance of MALDI-TOF MS for the identification of Candida species, species distribution, outcome, and susceptibility pattern. Infection. 2014;42:393-404.

20. Kolecka A, Khayhan K, Groenewald M, Theelen B, Arabatzis M, Velegraki A, et al. Identification of medically relevant species of arthroconidial yeasts by use of matrix-assisted laser desorption ionization-time of flight mass spectrometry. J Clin Microbiol. 2013;51:2491-500.

21. Guinea J. Global trends in the distribution of Candida species causing candidemia. Clin Microbiol Infect. 2014;20:5-10. https://doi.org/10.1111/ 1469-0691.12539.

22. Hou X, Xiao M, Chen SC, Wang H, Yu S, Fan X. Identification and Antifungal Susceptibility Profiles of Candida nivariensis and Candida bracarensis in a Multi-Center Chinese Collection of Yeasts. 2017:8 January:1-8.

23. Romeo O, Scordino F, Pernice I, Lo Passo C, Criseo G. A multiplex PCR protocol for rapid identification of Candida glabrata and its phylogenetically related species Candida nivariensis and Candida bracarensis. J Microbiol Methods. 2009;79:117-20. https://doi.org/10.1016/j.mimet.2009.07.016.

24. Borman AM, Petch R, Linton CJ, Palmer MD, Bridge PD, Johnson EM. Candida nivariensis, an emerging pathogenic fungus with multidrug resistance to antifungal agents. J Clin Microbiol. 2008;46:933-8.

25. Yazdanparast SA, Khodavaisy S, Fakhim H, Shokohi T, Haghani I, Nabili M, et al. Molecular characterization of highly susceptible Candida africana from vulvovaginal candidiasis. Mycopathologia. 2015;180:317-23.

26. Gácser A, Schäfer W, Nosanchuk JS, Salomon S, Nosanchuk JD. Virulence of Candida parapsilosis, Candida orthopsilosis, and Candida metapsilosis in reconstituted human tissue models. Fungal Genet Biol. 2007:44:1336-41.

27. Borman AM, Szekely A, Linton CJ, Palmer MD, Brown P, Johnson EM. Epidemiology, antifungal susceptibility, and pathogenicity of Candida africana isolates from the United Kingdom. J Clin Microbiol. 2013;51:967-72.

28. Rodríguez-Lequizamón G, Fiori A, López LF, Gómez BL, Parra-Giraldo CM, Gómez-López A, et al. Characterising atypical Candida albicans clinical isolates from six third-level hospitals in Bogotá, Colombia. BMC Microbiol 2015;15:1-10. doi:https://doi.org/10.1186/s12866-015-0535-0.

29. Campa D, Tavanti A, Gemignani F, Mogavero CS, Bellini I, Bottari F, et al. DNA microarray based on arrayed-primer extension technique for identification of pathogenic fungi responsible for invasive and superficial mycoses. J Clin Microbiol. 2008:46:909-15.

30. Borman AM, Linton CJ, Oliver D, Palmer MD, Szekely A, Odds FC, et al. Pyrosequencing analysis of 20 nucleotides of internal transcribed spacer 2 discriminates Candida parapsilosis, Candida metapsilosis, and Candida orthopsilosis. J Clin Microbiol. 2009:47:2307-10.

31. Jamal WY, Ahmad S, Khan ZU, Rotimi VO. Comparative evaluation of two matrix-assisted laser desorption/ionization time-of-flight mass spectrometry (MALDI-TOF MS) systems for the identification of clinically significant yeasts. Int J Infect Dis. 2014;26:167-70. https://doi.org/10.1016/j.ijid.2014.05.031.

32. Kim T-H, Kweon OJ, Kim HR, Lee M-K. Identification of uncommon Candida species using commercial identification systems. J Microbiol Biotechnol. 2016;26:2206-13. https://doi.org/10.4014/jmb.1609.09012. 
33. Sow D, Fall B, Ndiaye M, Ba BS, Sylla K, Tine R, et al. Usefulness of MALDITOF mass spectrometry for routine identification of Candida species in a resource-poor setting. Mycopathologia. 2015;180:173-9.

34. Posteraro B, Efremov L, Leoncini E, Amore R, Posteraro P, Ricciardi W, et al. Are the conventional commercial yeast identification methods still helpful in the era of new clinical microbiology diagnostics? A meta-analysis of their accuracy. J Clin Microbiol. 2015;53:2439-50.

35. Posteraro B, De Carolis E, Vella A, Sanguinetti M. MALDI-TOF mass spectrometry in the clinical mycology laboratory: identification of fungi and beyond. Expert Rev Proteomics 2013;10:151-164.

36. Clark AE, Kaleta EJ, Arora A, Wolk DM. Matrix-assisted laser desorption ionization-time of flight mass spectrometry: a fundamental shift in the routine practice of clinical microbiology. Clin Microbiol Rev. 2013;26:547-603.

37. Cornet M, Sendid B, Fradin C, Gaillardin C, Poulain D, Nguyen HV. Molecular identification of closely related Candida species using two ribosomal intergenic spacer fingerprinting methods. J Mol Diagnostics. 2011;13:12-22. https://doi.org/10.1016/j.jmoldx.2010.11.014.

38. Bishop JA, Chase N, Lee R, Kurtzman CP, Merz WG. Production of white colonies on CHROMagar Candida medium by members of the Candida glabrata clade and other species with overlapping phenotypic traits. J Clin Microbiol. 2008:46:3498-500.

39. Cendejas-Bueno E, Gomez-Lopez A, Mellado E, Rodriguez-Tudela JL, Cuenca-Estrella M. Identification of pathogenic rare yeast species in clinical samples: comparison between phenotypical and molecular methods. J Clin Microbiol. 2010;48:1895-9.

40. Albaina O, Sahand IH, Brusca MI, Sullivan DJ, De Larrinoa IF, Moragues MD. Identification and characterization of nine atypical Candida dubliniensis clinical isolates. J Med Microbiol 2015;64:147-156.

41. Romeo O, Criseo G. Candida africana and its closest relatives. Mycoses. 2011; 54:475-86.

Ready to submit your research? Choose BMC and benefit from:

- fast, convenient online submission

- thorough peer review by experienced researchers in your field

- rapid publication on acceptance

- support for research data, including large and complex data types

- gold Open Access which fosters wider collaboration and increased citations

- maximum visibility for your research: over $100 \mathrm{M}$ website views per year

At $\mathrm{BMC}$, research is always in progress.

Learn more biomedcentral.com/submissions 